\title{
Cutaneous lupus erythematosus. Diagnostic and therapeutic recommendations of the Polish Dermatological Society
}

\section{Skórna postać tocznia rumieniowatego. Rekomendacje diagnostyczno-terapeutyczne Polskiego Towarzystwa Dermatologicznego}

\begin{abstract}
Anna Woźniacka', Anna Sysa-Jędrzejowska², Adam Reich³ ${ }^{3}$ Jacek Szepietowski ${ }^{4}$, Maria Błaszczyk ${ }^{5}$,
\end{abstract} Anna Lis-Święty ${ }^{6}$, Anna Wojas-Pelc ${ }^{7}$, Dorota Krasowska ${ }^{8}$, Joanna Maj ${ }^{4}$, Lidia Rudnicka ${ }^{5}$

\author{
'Department of Dermatology and Venereology, Medical University of Lodz, Poland \\ 2University of Social Sciences, Lodz, Poland \\ ${ }^{3}$ Department of Dermatology, University of Rzeszow, Poland \\ ${ }^{4}$ Department of Dermatology, Venereology and Allergology, Wroclaw Medical University, Poland \\ ${ }^{5}$ Department of Dermatology, Medical University of Warsaw, Poland \\ ${ }^{6}$ Department of Dermatology, Medical University of Silesia, Katowice, Poland \\ ${ }^{7}$ Department of Dermatology and Venereology, Jagiellonian University Medical College, Krakow, Poland \\ ${ }^{8}$ Department of Dermatology, Venerology and Paediatric Dermatology, Medical University of Lublin, Poland \\ 'Katedra i Klinika Dermatologii i Wenerologii Uniwersytetu Medycznego w Łodzi, Polska \\ 2Społeczna Akademia Nauk w Łodzi, Polska \\ ${ }^{3}$ Zakład i Klinika Dermatologii Uniwersytetu Rzeszowskiego, Polska \\ ${ }^{4}$ Katedra i Klinika Dermatologii, Wenerologii i Alergologii Uniwersytetu Medycznego we Wrocławiu, Polska \\ ${ }^{5}$ Katedra i Klinika Dermatologiczna Warszawskiego Uniwersytetu Medycznego, Polska \\ ${ }^{6}$ Katedra i Klinika Dermatologii Śląskiego Uniwersytetu Medycznego w Katowicach, Polska \\ ${ }^{7}$ Katedra i Klinika Dermatologii i Wenerologii Collegium Medicum Uniwersytetu Jagiellońskiego w Krakowie, Polska \\ ${ }^{8}$ Katedra i Klinika Dermatologii, Wenerologii i Dermatologii Dziecięcej Uniwersytetu Medycznego w Lublinie, Polska
}

Dermatol Rev/Przegl Dermatol 2018, 105, 244-263 DOI: https://doi.org/l0.5 | |4/dr.2018.7558|

\author{
CORRESPONDING AUTHOR/ \\ ADRES DO KORESPONDENCJI: \\ prof. dr hab. n. med. \\ Anna Woźniacka \\ Katedra i Klinika Dermatologii \\ i Wenerologii \\ Uniwersytet Medyczny \\ pl. Hallera 1 bud. 6 \\ 91-647 Łódź, Polska \\ tel.: +48 426867981 , \\ +48606506881 \\ e-mail: wozniacka@bmp.net.pl
}

\begin{abstract}
Lupus erythematosus is an autoimmune disease with complex and not fully elucidated pathogenic mechanisms, the most important of which is the presence of antibodies directed against the autoantigens, particularly located within the cell nucleus, which precede the development of clinical symptoms. Lupus erythematosus either affects only the skin or skin lesions are one of the manifestations of a systemic process. The classification is based on morphological, histopathological and serological features, and the course of the disease. Depending on diverse clinical manifestations and differences in prognosis, therapeutic management needs to be adapted to the individual patient. Therapeutic guidelines include both lifestyle modifications (photoprotection, avoidance of infections, stress factors, phototoxic and photoallergic drugs, and oestrogens; supplementation with vitamin D), and topical (glucocorticosteroids, calcineurin inhibitors) and systemic medications. Antimalarials or systemic glucocorticosteroids are recommended in the treatment of patients with severe or disseminated lesions, with a tendency to scarring or a high risk of systemic organ involvement. Methotrexate, retinoids, sulphones and mycophenolate mofetil belong to second and third-line medications indicated for the treatment of cutaneous forms of lupus erythematosus.
\end{abstract}




\section{STRESZCZENIE}

Toczeń rumieniowaty jest chorobą autoimmunizacyjną o złożonych i nie $\mathrm{w}$ pełni poznanych mechanizmach patogenetycznych, wśród których największe znaczenie ma, wyprzedzająca objawy kliniczne, obecność przeciwciał skierowanych przeciwko własnym antygenom, zwłaszcza umiejscowionym w obrębie jądra komórkowego. Choroba może dotyczyć wyłącznie skóry lub też zmiany skórne mogą być jednym z elementów procesu ogólnoustrojowego. Klasyfikacja tocznia rumieniowatego opiera się na charakterystycznych cechach morfologicznych, histopatologicznych, serologicznych i przebiegu procesu chorobowego. Ze względu na różnorodny obraz kliniczny i odmienne rokowanie sposób leczenia powinien być ustalany indywidualnie. W zaleceniach terapeutycznych uwzględnia się zarówno styl życia (fotoprotekcja, unikanie infekcji, czynników stresogennych, leków o działaniu fototoksycznym i fotoalergicznym oraz estrogenów, suplementacja witaminą D), jak i leki miejscowe (glikokortykosteroidy, inhibitory kalcyneuryny) oraz ogólne. W przypadku obecności zmian nasilonych lub rozsianych, tendencji do bliznowacenia lub ryzyka rozwoju zmian narządowych zalecane jest leczenie preparatami przeciwmalarycznymi lub glikokortykosteroidami ogólnie. Metotreksat, retinoidy, sulfony i mykofenolan mofetylu należą do leków drugiego i trzeciego wyboru w terapii skórnych postaci tocznia rumieniowatego.

Key words: lupus erythematosus, consensus, Polish Dermatological Society.

Słowa kluczowe: toczeń rumieniowaty, konsensus, Polskie Towarzystwo Dermatologiczne.

\section{INTRODUCTION}

Lupus erythematosus (LE) is an autoimmune disease with complex and not fully elucidated pathogenic mechanisms, the most important of which is the presence of antibodies directed against the body's own antigens, particularly located within the cell nucleus, which precede the development of clinical symptoms [1]. Immune complexes forming in the circulation are deposited in internal organs and the skin, contributing to the development of inflammation followed by characteristic clinical manifestations and organ dysfunctions. The disease is characterized by periods of remission and recurrence which are typically induced by exposure to UV radiation, infection, stress, hormonal factors (oestrogens) as well as medications (usually procainamide and hydralazine) [2]. Lupus erythematosus is confined only to the skin (cutaneous lupus erythematosus - CLE) or skin lesions are a manifestation of multiple abnormalities of internal organs (systemic lupus erythematosus - SLE). They occur in 72-85\% of SLE patients and are associated with a rich symptomatology [3].

Lupus-specific cutaneous manifestations may present as acute cutaneous lupus erythematosus

\section{WPROWADZENIE}

Toczeń rumieniowaty (lupus erythematosus - LE) jest chorobą autoimmunizacyjną o złożonych i nie w pełni poznanych mechanizmach patogenetycznych, wśród których największe znaczenie ma, wyprzedzająca objawy kliniczne, obecność przeciwciał skierowanych przeciwko własnym antygenom, zwłaszcza umiejscowionym w obrębie jądra komórkowego [1]. Tworzące się w krążeniu kompleksy immunologiczne odkładają się w narządach. W skórze przyczyniają się do rozwoju stanu zapalnego, a następnie charakterystycznych zmian klinicznych i dysfunkcji narządowych. Choroba przebiega z okresami remisji i nawrotów, które zwykle są prowokowane ekspozycją na promieniowanie ultrafioletowe, infekcją, stresem, czynnikami hormonalnymi (estrogeny), a także lekami (najczęściej prokainamid i hydralazyna) [2]. Toczeń rumieniowaty może dotyczyć wyłącznie skóry (cutaneous lupus erythematosus - CLE) lub też zmiany skórne mogą być elementem licznych zaburzeń w narządach wewnętrznych (toczeń rumieniowaty układowy, systemic lupus erythematosus SLE). Występują one u 72-85\% chorych na SLE i cechują się bogatą symptomatologią [3].

Specyficzne dla tocznia wykwity skórne mogą mieć charakter ostry (acute cutaneous lupus erythematosus - 
(ACLE), subacute cutaneous lupus erythematosus (SCLE) or chronic cutaneous lupus erythematosus (CCLE) [4]. Lupus erythematosus tumidus (LET) is considered to be a distinct clinical subtype (intermittent cutaneous lupus erythematosus - ICLE) by some authors [5], whereas other authors classify skin eruptions of this type as belonging to chronic cutaneous lesions (CCLE) [4].

If antinuclear antibodies (ANA) are found in the patient's blood serum, skin lesions can be a manifestation of systemic disease. SLE-specific antibodies include antibodies directed against native DNA (anti-double stranded DNA - anti-dsDNA), antibodies reacting with the $\mathrm{Sm}$ antigen (anti-Sm) or antiphospholipid antibodies [4, 6-8].

\section{SKIN LESIONS AND CLASSIFICATION CRITERIA OF SYSTEMIC LUPUS ERYTHEMATOSUS}

The diagnosis of SLE is based on clinical examination and results of additional tests. A classificatory instrument often used for diagnostic purposes is the classification developed by ACR (American College of Rheumatology) in 1997 and including criteria divided into skin-related, organ-related and laboratory abnormalities. Based on the criteria, skin lesions secondary to SLE include malar (butterfly) rash, discoid lupus erythematosus (DLE), hypersensitivity to UV radiation, and ulcers or erosions (usually non-tender) affecting the mucosa of the oral cavity or, less commonly, the nose and the genital region [5].

In 2012 the Subcommittee on Classification and Response Criteria (SLICC 2012) published new classification criteria for SLE (table 1) which are based on a much wider spectrum of dermatological manifestations. To diagnose SLE, a patient must satisfy four criteria including at least one of the clinical criteria and one of the immunologic criteria. The only exception is lupus nephritis which can be diagnosed on the basis of histopathological evidence of the disease in kidney biopsy and the presence of antinuclear antibodies (ANA) or specific anti-dsDNA antibodies [4].

\section{MALAR RASH}

Acute skin lesions develop most commonly in women in the third decade of life and accompany the systemic form of lupus. The most characteristic cutaneous manifestation is malar rash - well-marginated erythema located on the cheeks and the bridge of the nose, resembling the shape of a butterfly. A typical clinical feature is that the rash spares the nasolabial folds. Skin lesions are often oedematous and exacer-
ACLE), podostry (subacute cutaneous lupus erythematosus SCLE) lub przewlekły (chronic cutaneous lupus erythematosus - CCLE) [4]. Postać obrzękowa tocznia (lupus erythematosus tumidus - LET) jest przez część autorów wyodrębniona i stanowi oddzielny podtyp kliniczny (intermittent cutaneous lupus erythematosus - ICLE) [5], natomiast pozostali badacze wykwity o tej postaci włączają do grupy przewlekłych zmian skórnych (CCLE) [4].

Jeśli w surowicy chorego stwierdza się obecność przeciwciał przeciwjądrowych (antinuclear antibodies - ANA), zmiany skórne mogą być elementem choroby ogólnoustrojowej. Za specyficzne dla SLE uznaje się przeciwciała skierowane przeciw natywnemu DNA (anti-double stranded DNA - anty-dsDNA), przeciwciała reagujące $z$ antygenem $\mathrm{Sm}$ (anty-Sm) lub przeciwciała przeciwfosfolipidowe [4, 6-8].

\section{ZMIANY SKÓRNE A KRYTERIA KLASYFIKACYJNE TOCZNIA RUMIENIOWATEGO UKŁADOWEGO}

Rozpoznanie SLE opiera się na badaniu klinicznym i wynikach badań dodatkowych. Do celów diagnostycznych wykorzystuje się często kryteria klasyfikacyjne ACR (American College of Rheumatology) z 1997 r. uwzględniające objawy skórne, narządowe i odchylenia w badaniach laboratoryjnych. Według nich do zmian skórnych w przebiegu SLE należą: rumień na twarzy o typie motyla (malar rash, butterfly rash), toczeń rumieniowaty ogniskowy (discoid lupus erythematosus - DLE), nadwrażliwość na promieniowanie UV oraz niebolesne zazwyczaj owrzodzenia lub nadżerki zlokalizowane w obrębie błony śluzowej jamy ustnej lub rzadziej nosa i okolic narządów płciowych [5].

W 2012 r. grupa Subcommittee on Classification and Response Criteria (SLICC 2012) opracowała nowe kryteria klasyfikacyjne dla SLE (tab. 1), w których uwzględniono znacznie szersze spektrum objawów dermatologicznych. Do rozpoznania SLE niezbędne jest spełnienie czterech kryteriów, w tym co najmniej jedno musi być kryterium klinicznym i co najmniej jedno kryterium immunologicznym. Wyjątek stanowi toczniowe zapalenie nerek, do którego rozpoznania wystarczające jest potwierdzenie histopatologiczne choroby w biopsji nerek oraz obecności przeciwciał przeciwjądrowych lub swoistych przeciwciał anty-dsDNA [4].

\section{RUMIEŃ NA TWARZY O TYPIE MOTYLA}

Zmiany skórne o ostrym charakterze występują najczęściej u kobiet będących w trzeciej dekadzie życia i towarzyszą postaci układowej tocznia. Najbardziej charakterystyczny jest dobrze odgraniczony rumień twarzy zlokalizowany na policzkach i grzbiecie nosa, przypominający kształtem motyla. Typową cechą kliniczną jest brak zajęcia fałdów nosowo-wargowych. Zmiany mają często charakter obrzękowy, nasilają się pod wpływem ekspozycji na promienio- 
Table I. SLICC 2012 classification criteria for systemic lupus erythematosus [4]

\begin{tabular}{|c|c|}
\hline & Clinical criteria \\
\hline & I. Acute cutaneous lesions: \\
\hline & lupus malar rash \\
\hline & bullous skin lesions \\
\hline & toxic epidermal necrolysis variant of SLE \\
\hline & maculopapular rash \\
\hline & maculopapular rash induced by exposure to UV radiation \\
\hline & or SCLE-type lesions \\
\hline & 2. Chronic cutaneous lesions: \\
\hline & discoid lupus erythematosus (DLE) \\
\hline & hypertrophic (verrucous) lesions \\
\hline & lupus panniculitis \\
\hline & mucosal lupus \\
\hline & lupus tumidus \\
\hline & chilblain lupus \\
\hline & discoid lupus/ichen planus overlap \\
\hline & 3. Oral ulcers (palate, buccal mucosa, tongue) or nasal mucosal ulcers \\
\hline & 4. Non-scarring alopecia - diffuse thinning and fragility of hair with visible hair loss \\
\hline & $\begin{array}{l}\text { 5. Synovitis involving two or more joints, characterized by swelling or effusion or tenderness in two or more joints and at least } \\
30 \text { min of morning stiffness }\end{array}$ \\
\hline & 6. Serositis: \\
\hline & typical pleurisy for more than I day, pleural effusion or pleural rub \\
\hline & typical pericardial pain for more than I day, pericardial effusion, pericardial rub or pericarditis confirmed by electrocardiography \\
\hline & 7. Renal involvement: \\
\hline & over $500 \mathrm{mg}$ of protein in 24-hour urine collection or presence of red blood cell casts \\
\hline & 8. Neurologic abnormalities: \\
\hline & seizures \\
\hline & psychosis \\
\hline & mononeuritis multiplex - in the absence of other known causes such as primary vasculitis \\
\hline & myelitis \\
\hline & peripheral and cerebral neuropathy - in the absence of other known causes such as primary vasculitis, infection, diabetes mellitus, \\
\hline & acute confusional state - in the absence of other known causes such toxic/metabolic disorders, uraemia, drugs \\
\hline & 9. Haemolytic anaemia \\
\hline & I0. Leukopaenia ( $<4000 / \mathrm{mm}^{3}$ at least once) or lymphopaenia $\left(<1000 / \mathrm{mm}^{3}\right.$ at least once - in the absence of other known causes) \\
\hline & $\begin{array}{l}\text { I I. Thrombocytopaenia (< } 100000 \mathrm{~mm}^{3} \text { at least once - in the absence of other known causes such as drugs, portal hypertension, thrombotic } \\
\text { thrombocytopaenic purpura - TTP) }\end{array}$ \\
\hline & Immunologic criteria \\
\hline & I. ANA level above the reference range \\
\hline & 2. Anti-dsDNA above the reference range (or $>$ twofold the reference range if tested by ELISA) \\
\hline & 3. Anti-Sm - presence of antibodies to the Sm nuclear antigen \\
\hline & $\begin{array}{l}\text { 4. Antiphospholipid antibodies detected by various methods: lupus anticoagulant (LAC), false-positive syphilis test result, medium or high titre } \\
\left.\text { of anticardiolipin antibodies (IgA, } \lg G \text { or } \lg M) \text {, positive test result for anti- } \beta_{2} \text {-glycoprotein antibodies (IgA, } \lg G, \lg M\right)\end{array}$ \\
\hline & 5. Reduced complement level: low C3, low C4, low CH50 \\
\hline & 6. Positive Coombs' test in the absence of haemolytic anaemia \\
\hline
\end{tabular}

bate as a result of sun exposure. They are correlated with SLE activity and resolve without scarring or hyperpigmentation.

\section{BULLOUS LUPUS ERYTHEMATOSUS}

Bullous lupus erythematosus (BLE) is regarded as a subepidermal bullous disorder associated with the presence of antibodies directed against collagen VII. wanie słoneczne, korelują z aktywnością SLE i ustępują bez pozostawienia blizn i przebarwień.

\section{POSTAĆ PĘCHERZOWA TOCZNIA}

Pęcherzowa postać tocznia układowego (bullous lupus erythematosus - BLE) uznawana jest za podnaskórkową chorobę pęcherzową, zależną od przeciwciał skierowanych przeciwko kolagenowi typu VII. Występuje rzadko, 
Tabela I. Kryteria klasyfikacyjne tocznia rumieniowatego układowego wg SLICC z 2012 r. [4]

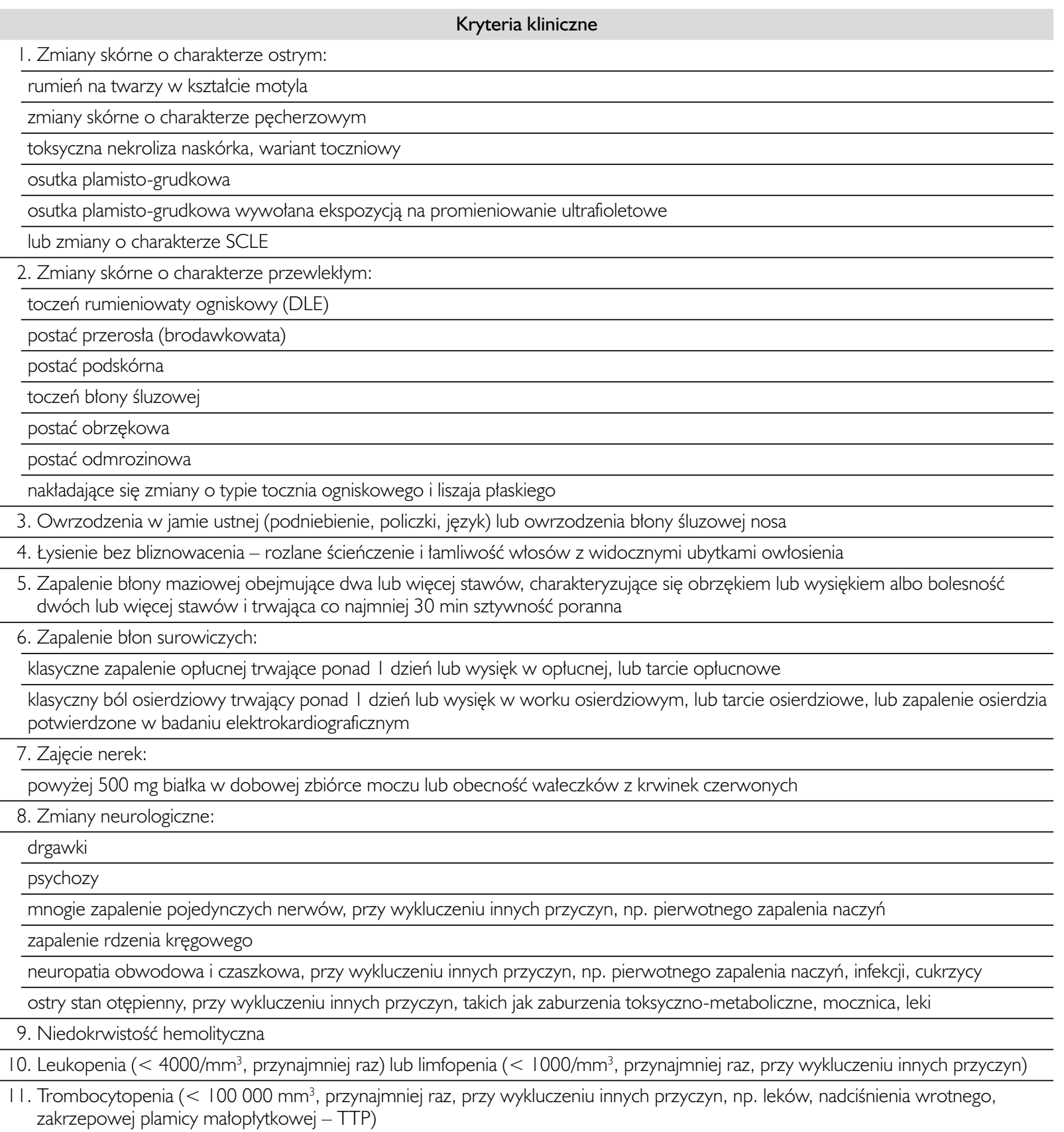

\section{Kryteria immunologiczne}

I. ANA powyżej wartości referencyjnych

2. Anty-dsDNA powyżej wartości referencyjnych (lub > 2 razy powyżej wartości referencyjnych w przypadku metody ELISA)

3. Anty-Sm - obecność przeciwciał skierowanych przeciwko antygenowi jądrowemu Sm

4. Przeciwciała antyfosfolipidowe wykrywane różnymi metodami, takimi jak LAC (lupus anticoagulant), fałszywie dodatni test kiłowy, średnie lub wysokie miano przeciwciał antykardiolipinowych (IgA, IgG lub IgM), dodatni test na obecność przeciwciał przeciwko $\beta_{2}$-glikoproteinie (lgA, $\left.\lg \mathrm{G}, \lg M\right)$

5. Obniżone miano dopełniacza: niski C3, niski C4, niski CH50

6. Dodatni test Coombsa u osoby bez niedokrwistości hemolitycznej 
Bullous lupus erythematosus occurs rarely, in just 5\% of all lupus patients, affecting mainly young women, more commonly with skin phototype IV. Lesions always coexist with SLE. Occasionally, they may be the first manifestation of the disease, and they are typically associated with a severe course and renal involvement. Skin lesions manifest as tense bullae or vesicles which resolve without scarring or milia. Even though eruptions may affect all body sites, they are more commonly located on the upper trunk, on the upper extremities, face, neck and the rubor labiorum area. Mucous membranes are also involved. Bullae usually arise on an erythematous base, however they may also develop on unaltered skin. They are filled with serous fluid which, after their rupture, dries up to form thick scabs.

The histopathological pattern shares a range of similarities with dermatitis herpetiformis. Typical findings include subepidermal bullae and neutrophil infiltrates in the papillary layer of the dermis, localized specifically around papillae. Direct immunofluorescence of lesional skin or surrounding non-lesional skin usually shows linear or granular deposits of IgG, less commonly IgA and IgM, at the dermal-epidermal junction. Salt-split skin test (splitting of the skin within the basal layer) shows fluorescence on the dermal side of the artificially split skin. Serum may contain antibodies against the basement membrane $[9,10]$.

\section{TOXIC EPIDERMAL NECROLYSIS VARIANT OF SYSTEMIC LUPUS ERYTHEMATOSUS}

Toxic epidermal necrolysis variant of SLE is a relatively recently described form of skin lesions which is usually associated with a severe disease course [11] and often develops after intensive UV exposure. It is a clinical variant observed more frequently in SLE, and less commonly in SCLE. Lesions occur in sites of previous eruptions characteristic of lupus and gradually spread over the entire skin surface. Macular, papular and erythematous rash covers large areas of the skin, with relatively tense bullae forming within them. Rubbing of the bullous area results in exfoliation of the epidermis (positive Nikolsky's sign). It is caused by separation of the epidermis from the dermis due to massive apoptosis of cells in the basal layer. Skin lesions resolve usually without any scarring and occasionally with slight hyperpigmentation [12].

\section{MACULOPAPULAR RASH}

Skin eruptions with an acute presentation and course may also manifest as generalized acute cutaneous lupus erythematosus, a condition resembling jedynie u 5\% chorych na toczeń. Dotyczy zwykle młodych kobiet, częściej z IV fototypem skóry. Zmiany zawsze współistnieją z SLE, niekiedy mogą być pierwszym objawem choroby, zwykle łączą się z jej ciężkim przebiegiem i zajęciem nerek. Zmiany skórne mają postać pęcherzy lub pęcherzyków o dobrze napiętej pokrywie, które ustępują bez pozostawienia blizn i prosaków. Chociaż wykwity mogą dotyczyć każdej okolicy skóry, to częściej zlokalizowane są w górnych częściach tułowia, na konczynach górnych, szyi, twarzy i w okolicy czerwieni wargowej. Zajmują również błonę śluzową. Pęcherze zwykle rozwijają się na rumieniowej podstawie, ale mogą być obecne w obrębie skóry niezmienionej. Zawierają treść surowiczą, która po pęknięciu pokrywy zasycha, tworząc uwarstwione strupy.

Obraz histopatologiczny wykazuje wiele podobieństw do opryszczkowatego zapalenia skóry (dermatitis herpetiformis). Obecny jest pęcherz podnaskórkowy i nacieki z neutrofilów w warstwie brodawkowatej skóry, które koncentrują się zwłaszcza w okolicy brodawek skóry. W bezpośrednim badaniu immunofluorescencyjnym (ze zmian skórnych lub skóry otaczającej) najczęściej stwierdza się linijne lub ziarniste złogi IgG, rzadziej IgA i IgM zlokalizowane na granicy skórno-naskórkowej. W badaniu metodą splitu skórnego (rozwarstwienie skóry w obrębie warstwy podstawnej) widoczne jest świecenie wzdłuż dermalnej strony sztucznie utworzonego pęcherza. W surowicy mogą być obecne przeciwciała skierowane przeciwko błonie podstawnej $[9,10]$.

\section{TOKSYCZNA NEKROLIZA NASKÓRKA, TZW. WARIANT TOCZNIOWY}

Jest to niedawno opisana forma zmian skórnych, która zwykle występuje w przebiegu znacznie nasilonego procesu chorobowego [11] i często pojawia się po intensywnej ekspozycji na UV. Tę postać kliniczną obserwuje się częściej w przebiegu SLE, rzadziej SCLE. Zmiany występują w miejscach wcześniej istniejących wykwitów typowych dla tocznia, a następnie rozprzestrzeniają się na całą powierzchnię skóry. Plamy, grudki i rumienie zajmują duże powierzchnie, a w ich obrębie tworzą się pęcherze o dość dobrze napiętej pokrywie. Przy pocieraniu okolic pęcherza obserwuje się spełzanie naskórka (objaw Nikolskiego). Jest on wyrazem oddzielania się naskórka od skóry właściwej spowodowanego masywną apoptozą komórek warstwy podstawnej. Zmiany zwykle ustępują bez pozostawienia blizny, niekiedy z nieznacznym przebarwieniem [12].

\section{OSUTKA PLAMISTO-GRUDKOWA}

Wykwity o ostrym charakterze i przebiegu mogą objawiać się także jako uogólniona osutka plamisto-grudkowa (generalized acute cutaneous lupus ery- 
drug-induced skin reactions or measles-like rash. Skin lesions are located symmetrically, involving the trunk and the extremities, and often coexist with vascular abnormalities. Nail folds are affected by erythema, vascular dilatation and cuticular hypertrophy.

\section{MACULOPAPULAR RASH INDUCED BY EXPOSURE TO ULTRAVIOLET RADIATION}

Patients with lupus often report hypersensitivity to sunlight. Sun-exposed sites tend to be affected by erythematous lesions, the severity of which is out of proportion to the duration of exposure. Also, photoprovocation is observed in some patients, with skin lesions characteristic of lupus appearing a few days, up to a few weeks, after irradiation. Since the period between sun exposure and development of lesions is long, patients fail to note the causal relationship. Photoprovocation can also be induced in the experimental setting. The phenomenon provides evidence for the aetiopathogenetic role of UV radiation in the formation of cutaneous lesions secondary to lupus [13].

\section{SUBACUTE CUTANEOUS LUPUS ERYTHEMATOSUS}

Subacute cutaneous lupus erythematosus may present as annular or psoriasiform lesions. They are typically located on the trunk and on the extensor surfaces of the upper extremities, and rarely occur below the hip line. The primary lesions of subacute cutaneous lupus erythematosus are papules which gradually coalesce into annular or psoriasiform plaques. Occasionally, both types of lesions coexist in the same patient. The presence of either annular or psoriasiform lesions is not a factor determining the course of the disease. Even though patients report extreme hypersensitivity to solar radiation, skin eruptions are rarely located on the face. Lesions persist for a few weeks to a few months, and tend to resolve without scarring or atrophy. However, post-inflammatory depigmentation of the skin, resembling foci of vitiligo, is often observed. Occasionally, small vesicles resulting from the vacuolization of cells in the basal layer of the epidermis are seen on the periphery. Antibodies to the Ro antigen (anti-Ro), detected in over a half of all patients, are an immunological marker of the disease. Less often, anti-Ro antibodies coexist with anti-La antibodies. Although approximately 50\% of SCLE-affected patients also have SLE, the course of the disease in these cases is mild, without neurological, vascular or renal symptoms. Prominent manifestations of SCLE thematosus), przypominająca zmiany polekowe lub zmiany w przebiegu odry. Wykwity zlokalizowane są symetrycznie, zajmują tułów i kończyny, często towarzyszą im zmiany naczyniowe. W obrębie wałów paznokciowych widoczny jest rumien, poszerzenie naczyń i przerost oskórka.

\section{OSUTKA PLAMISTO-GRUDKOWA WYWOŁANA EKSPOZYCJA NA PROMIENIOWANIE ULTRAFIOLETOWE}

Chorzy na toczeń często zgłaszają nadwrażliwość na promieniowanie słoneczne. Zwykle w miejscach odsłoniętych występują zmiany rumieniowe, których intensywność jest nieadekwatna do czasu ekspozycji. U części pacjentów obserwuje się zjawisko fotoprowokacji zmian skórnych, tj. powstawania wykwitów typowych dla tocznia po kilku dniach lub nawet tygodniach od naświetlania. Ze względu na długi czas od ekspozycji na słońce pacjenci nie kojarzą tych zależności. Fotoprowokację można również wywołać w warunkach doświadczalnych. Zjawisko to potwierdza etiopatogenetyczną rolę promieniowania UV $\mathrm{w}$ rozwoju zmian skórnych w przebiegu tocznia [13].

\section{PODOSTRA SKÓRNA POSTAĆ TOCZNIA RUMIENIOWATEGO}

Podostra skórna postać tocznia rumieniowatego może występować w formie zmian obrączkowatych lub łuszczycopodobnych. Wykwity zwykle lokalizują się na tułowiu i kończynach górnych po stronie wyprostnej, rzadko widoczne są poniżej linii bioder. Początkowo mają one postać grudkową, a następnie szerząc się, tworzą ogniska obrączkowate lub przypominające łuszczycę. Niekiedy te dwa typy zmian współistnieją jednocześnie u tego samego pacjenta. Obecność formy obrączkowatej lub łuszczycopodobnej nie wpływa na określony przebieg procesu chorobowego. Chociaż pacjenci zgłaszają wybitną nadwrażliwość na promieniowanie słoneczne, wykwity rzadko lokalizują się na twarzy. Zmiany utrzymują się kilka tygodni, a nawet miesięcy, ustępują bez pozostawiania blizn i zaników, natomiast często obserwuje się pozapalne odbarwienie skóry przypominające ogniska bielacze. Niekiedy na obwodzie widoczne są drobne pęcherzyki powstałe w wyniku wakuolizacji komórek warstwy podstawnej naskórka. Immunologicznym markerem choroby są przeciwciała skierowane przeciwko antygenowi Ro (anty-Ro), które wykrywane są u ponad połowy pacjentów. Rzadziej przeciwciała te współistnieją z przeciwciałami anty-La. Chociaż u 50\% przypadków chorych na SCLE można rozpoznać również toczeń układowy, to jednak przebieg choroby w tych przypadkach jest łagodny, bez objawów neurologicznych, naczyniowych 
include muscle and joint pain and, less commonly, features of inflammation in more than two joints. A frequent coexisting symptom is mucosal dryness (secondary Sjögren syndrome). This subtype is more commonly triggered by drugs than other cutaneous forms of LE [14].

\section{DISCOID LUPUS ERYTHEMATOSUS}

Discoid lupus erythematosus (DLE) is among the most prevalent chronic skin conditions. Depending on the location of the skin lesions, it can be subdivided into localized (DLE) and disseminated (disseminated discoid lupus erythematosus - DDLE) forms. In the localized form, lesions occur above the neck and tend to be confined to the scalp, face and auricles. In contrast, in the disseminated form skin eruptions affect areas both above and below the neck line. Skin lesions present as infiltrated erythematous foci of inflammation with characteristic follicular hyperkeratinization which causes follicles to appear uneven and rough to the touch. As the lesions persist, they develop a hypopigmented centre and hyperpigmented periphery. The emerging cicatricial atrophy is irreversible. Skin eruptions cause a severe and permanent cosmetic defect [15].

\section{HYPERTROPHIC (VERRUCOUS) DISCOID LUPUS ERYTHEMATOSUS}

Another chronic form of lupus erythematosus is hypertrophic (verrucous) DLE which is associated with chronically persisting and untreated skin lesions. Erythematous plaques are markedly thickened, infiltrated, and scaly on the surface. Chronic inflammation may stimulate the development of cancerous changes.

\section{LUPUS ERYTHEMATOSUS PANNICULITIS}

The subcutaneous (deep) form of lupus (lupus erythematosus panniculitis - LEP) is characterized by the presence of hard compact nodular infiltrates located in areas with prominent subcutaneous tissue, such as the arms, thighs, buttocks, cheeks and breasts (lupus mastitis). The skin surface may be smooth or exhibit features of DLE. Lesions rarely soften and usually resolve within a few weeks, leaving typical deep atrophic areas [16].

\section{MUCOSAL LUPUS}

Some patients develop white epithelial lesions (papules arranged in a tree-like pattern, usually i nerkowych. W przebiegu SCLE przeważają bóle mięśni i stawów, rzadziej cechy zapalenia więcej niż dwóch stawów. Często współwystępuje suchość błony śluzowej (wtórny zespół Sjögrena). Spośród różnych postaci skórnych LE ten podtyp jest częściej niż inne prowokowany przez leki [14].

\section{TOCZEŃ RUMIENIOWATY OGNISKOWY}

Toczeń rumieniowaty ogniskowy (discoid lupus erythematosus - DLE) należy do najczęściej występujących zmian skórnych o charakterze przewlekłym. W zależności od lokalizacji wykwitów wyróżnia się postać ograniczoną (DLE) i rozsianą (disseminated discoid lupus erythematosus - DDLE). W postaci ograniczonej zmiany lokalizują się powyżej linii karku, najczęściej w obrębie owłosionej skóry głowy, twarzy i małżowin usznych. W postaci rozsianej natomiast wykwity obecne są zarówno powyżej, jak i poniżej linii karku. Zmiany skórne mają postać rumieniowo-naciekowych ognisk zapalnych z charakterystycznym rogowaceniem ujść mieszków włosowych, które przy dotyku dają odczucie nierównej, szorstkiej powierzchni. Wraz z utrzymywaniem się zmian dochodzi do przebarwienia na obwodzie oraz odbarwienia w centrum. Tworzący się zanik bliznowaty ma charakter nieodwracalny. Wykwity są przyczyną poważnego i trwałego defektu kosmetycznego [15].

\section{POSTAĆ PRZEROSŁA (BRODAWKOWATA) TOCZNIA RUMIENIOWATEGO OGNISKOWEGO}

Do przewlekłych postaci tocznia należą również zmiany w postaci brodawkowatej (hypertrophic, verrucous DLE), które występują w przypadku wykwitów długo utrzymujących się i nieleczonych. Tarczki rumieniowe są wyraźnie pogrubiałe, nacieczone, ze złuszczaniem na powierzchni. Przewlekły stan zapalny może stymulować zmiany nowotworowe.

\section{POSTAĆ PODSKÓRNA}

Podskórna (głęboka) postać tocznia (lupus erythematosus panniculitis - LEP) cechuje się obecnością stwardniałych, spoistych nacieków guzowatych, które lokalizują się w miejscach nagromadzenia tkanki podskórnej, tj. na ramionach, udach, pośladkach, policzkach i piersiach (lupus mastitis). Powierzchnia skóry może być gładka lub też wykazywać cechy DLE. Zmiany rzadko rozmiękają, zwykle po kilku tygodniach ustępują z pozostawieniem charakterystycznych głębokich zaników [16].

\section{TOCZEŃ BŁONY ŚLUZOWEJ}

U części chorych zmiany o typie zmleczeń nabłonka (drzewkowato układające się grudki, najczęściej 
confined to sites of mechanical irritation), located on the buccal or gingival mucosa or in the rubor labiorum area. They do not cause any symptoms or produce only mild hypersensitivity, dryness or tenderness [17]. In isolated cases lesions affect mucous membranes in the genital area.

\section{LUPUS ERYTHEMATOSUS TUMIDUS}

Lupus erythematosus tumidus (LET) is characterized by the highest photosensitivity. Skin lesions present as elevated, oedematous, succulent, erythematous plaques with a smooth surface, located in sites exposed to sunlight. Plaques resolve without leaving scarring or atrophy, however they recur intermittently, particularly after exposure to UV radiation. In most cases, LET is confined only to the skin and rarely develops secondary to SLE [18].

\section{CHILBLAIN LUPUS}

Chilblain lupus is characterized by purple-red erythematous skin lesions resembling frostbite. To eliminate diagnostic difficulties, two major and three minor diagnostic criteria have been developed. Two major and at least one minor criteria must be met for making a diagnosis of this clinical form. Major criteria include the presence of erythematous skin lesions exacerbated by exposure to cold, located on distal parts of the body, and the presence of skin lesions specific to lupus erythematosus as determined by histopathological or immunopathological examination. Minor criteria comprise coexistence with SLE or CLE, improvement after specific anti-lupus therapy and absence of cryoglobulins in the blood serum [19].

\section{DISCOID LUPUS AND LICHEN PLANUS OVERLAP}

The form combines the clinical and histopathological features of both lupus erythematosus (LE) and lichen planus (LP). Erythematous and papular lesions of this type affect primarily the face or hands.

\section{MUCOSAL ULCERS}

The diagnostic criteria of SLE also include ulcertype lesions found in the oral cavity (palate, buccal regions and/or tongue) or within the nasal mucosa. Since the ulcers are usually non-tender, they are often not reported by patients. w miejscach mechanicznego drażnienia) obecne są na błonie śluzowej policzków, dziąseł lub czerwieni wargowej. Nie wywołują żadnych dolegliwości lub powodują nieznacznego stopnia nadwrażliwość, suchość lub bolesność [17]. W pojedynczych przypadkach zmiany występują na błonach śluzowych narządów płciowych.

\section{POSTAĆ OBRZĘKOWA}

Postać obrzękowa (LET) charakteryzuje się największą fotowrażliwością. Zmiany mają postać wyniosłych, obrzękowych, soczystych rumieni o gładkiej powierzchni, zlokalizowanych w miejscach eksponowanych na działanie promieniowania słonecznego. Ustępując, nie pozostawiają blizn ani zaników. Okresowo nawracają, zwłaszcza po ekspozycji na promieniowanie UV (intermittent). Zwykle postać ta dotyczy wyłącznie skóry, rzadko rozwija się w przebiegu SLE [18].

\section{POSTAĆ ODMROZINOWA}

Postać odmrozinowa (chilblain lupus) cechuje się obecnością sinoczerwonych rumieni przypominających odmrożenia. Ze względu na trudności w rozpoznawaniu opracowano dwa większe i trzy mniejsze kryteria diagnostyczne. Spełnienie dwóch większych i co najmniej jednego mniejszego umożliwia rozpoznanie tej postaci klinicznej. Do kryteriów większych należą: obecność zmian rumieniowych nasilających się pod wpływem zimna zlokalizowanych na dystalnych częściach ciała, obecność specyficznych dla tocznia zmian w badaniu histopatologicznym lub immunopatologicznym. Do kryteriów mniejszych zalicza się: współistnienie z SLE lub CLE, poprawa po leczeniu specyficznym dla tocznia oraz brak krioglobulin w surowicy [19].

\section{NAKŁADAJACEE SIĘ ZMIANY O TYPIE TOCZNIA OGNISKOWEGO I LISZAJA PŁASKIEGO}

Wyróżnia się również postać, w której zmiany zarówno w obrazie klinicznym, jak i histopatologicznym mają cechy tocznia rumieniowatego i liszaja płaskiego (LE/LP). Rumienie i grudki o tym charakterze lokalizują się zwykle na twarzy lub w obrębie rąk.

\section{OWRZODZENIA BŁONY ŚLUZOWEJ}

Jednym z kryteriów rozpoznania SLE są również zmiany o typie owrzodzeń obecne w jamie ustnej (podniebienie, policzki i/lub język) lub na błonie śluzowej nosa. Owrzodzenia zwykle nie powodują żadnych dolegliwości bólowych, dlatego często nie są zgłaszane przez pacjentów. 
Non-scarring alopecia represents another diagnostic criterion of SLE and manifests as marked hair thinning resulting from telogen effluvium. The hair of affected patients is dry, fragile and thin, with the most prominent lesions seen in the frontal area. Hair loss and exacerbation of alopecia may correlate with the activity of systemic disease. Trichoscopy usually makes it possible to rule out other causes of alopecia including scarring alopecia resulting from discoid lupus erythematosus of the scalp [20]. Treatment with systemic drugs (antimalarial medications, glucocorticosteroids, ciclosporin and other immunosuppressive drugs) often provides cosmetically acceptable or even complete hair regrowth, usually within 6 months.

\section{DIAGNOSIS OF LUPUS-SPECIFIC CUTANEOUS LESIONS}

In addition to the characteristic clinical presentation, a crucial factor in the diagnosis of specific cutaneous lesions is the histopathological examination revealing features of vacuolar degeneration of cells in the basal layer and lymphocytic infiltrates, either dispersed subepidermally or concentrated around the skin appendages. In cases with an acute course hyperkeratosis may be absent and the subepidermal infiltrate is dispersed. Diagnostic features include oedema within upper skin layers and focal vacuolar degeneration in the basal layer. In subacute or chronic forms, depending on the morphology of lesions, the epidermis may reveal no abnormalities or mild atrophy. Various degrees of follicular hyperkeratinization are also frequently observed. The reticular layer is usually affected by oedema and mucin deposits, especially in patients with lupus erythematosus tumidus. A more distinct form is bullous lupus erythematosus which, histopathologically, shares a number of similarities with dermatitis herpetiformis $[9,10]$.

The diagnostic procedure in cutaneous forms of lupus erythematosus also comprises direct immunofluorescence (DIF), a technique which makes it possible to evaluate the composition of deposits of immunoglobulins and complement components in the skin (so-called lupus band test). The examination is not as important as histopathological analysis and does not need to be performed on a routine basis. In uncertain cases, a skin biopsy may be taken, preferably from persistent lesions. A characteristic feature of cutaneous lupus is the presence of granular deposits of complement and/or IgG and/or IgM, rarely IgA, located at the dermal-epidermal junction and around hair follicles. Direct immunofluorescence in SCLE patients with circulating anti-Ro/SS-A anti-

\section{ŁYSIENIE NIEBLIZNOWACIEJĄCE}

Łysienie niebliznowaciejące stanowi kolejne kryterium diagnostyczne SLE, które cechuje się wyraźnym przerzedzeniem włosów $\mathrm{w}$ wyniku łysienia telogenowego. Włosy są suche, łamliwe i cienkie. Zwykle najbardziej nasilone zmiany są widoczne w okolicy czołowej. Wypadanie włosów i nasilenie łysienia mogą korelować z aktywnością choroby układowej. Trichoskopia pozwala zazwyczaj na wykluczenie innych przyczyn łysienia, $\mathrm{w}$ tym łysienia bliznowaciejącego wynikającego $\mathrm{z}$ występowania ogniskowej postaci tocznia w obrębie skóry owłosionej [20]. Włączenie leków działających ogólnie (preparaty przeciwmalaryczne, glikokortykosteroidy, cyklosporyna i inne leki immunosupresyjne) powoduje często kosmetycznie akceptowalny lub nawet całkowity odrost włosów, zwykle w czasie 6 miesięcy.

\section{ROZPOZNAWANIE SPECYFICZNYCH DLA TOCZNIA ZMIAN SKÓRNYCH}

W rozpoznawaniu specyficznych zmian skórnych, poza charakterystycznym obrazem klinicznym, duże znaczenie ma badanie histopatologiczne, w którym obecne są cechy zwyrodnienia wodniczkowego komórek warstwy podstawnej naskórka oraz nacieki złożone z limfocytów, rozproszone pod naskórkiem lub skupione wokól przydatków. W postaciach o ostrym przebiegu hiperkeratoza może być nieobecna, a naciek podnaskórkowy jest rozproszony. Do diagnostycznych cech należą obrzęk w obrębie górnych warstw skóry i ogniskowe zwyrodnienie wodniczkowe warstwy podstawnej. W postaciach o charakterze podostrym lub przewlekłym, w zależności od morfologii zmian, naskórek może być prawidłowy lub wykazywać niewielki zanik. Często widoczne jest różnie nasilone rogowacenie ujść mieszków włosowych. W warstwie siateczkowatej stwierdza się zwykle obrzęk i złogi mucyny, zwłaszcza w postaci obrzękowej. Pewną odrębność stanowi postać pęcherzowa, której obraz histopatologiczny wykazuje wiele podobieństw do opryszczkowatego zapalenia skóry $[9,10]$.

$\mathrm{W}$ diagnostyce skórnych postaci tocznia rumieniowatego stosuje się również badanie immunofluorescencyjne bezpośrednie (direct immunofluorescence - DIF), pozwalające na ocenę składu złogów immunoglobulin i składowych dopełniacza w skórze (lupus band test), które nie ma tak istotnego znaczenia jak badanie histopatologiczne i nie musi być wykonywane rutynowo. W przypadkach wątpliwych można pobrać wycinek, najlepiej ze zmian długo utrzymujących się. Dla tocznia skórnego charakterystyczna jest obecność ziarnistych złogów dopełniacza i/lub IgG, i/lub IgM, rzadko IgA zlokalizowanych na granicy skórno-naskórkowej i wokół mieszków włosowych. U chorych na SCLE z obecnością przeciwciał anty-Ro/SS-A w krążeniu w badaniu DIF obserwuje się niekiedy ziarniste złogi 
bodies occasionally shows granular deposits of IgG or IgM antibodies scattered in the epidermis (dustlike particles). The presence of immunoglobulin and/or complement deposits in unaffected skin is more typical of SLE.

\section{LUPUS NON-SPECIFIC CUTANEOUS LESIONS ACCOMPANYING SYSTEMIC LUPUS ERYTHEMATOSUS}

Lesions of this type occur frequently and are attributed to the involvement of blood vessels of different sizes. They manifest as ischaemic vasculopathies (Raynaud's phenomenon), vasculitis (urticaria vasculitis, purpura hyperergica, chronic and recurrent ulcers, fingertip necrosis), thrombotic vasculopathies (livedo racemosa, peripheral gangrene, subungual ecchymosis, ulcers), nail fold telangiectasias, subcutaneous nodules and recurrent superficial and deep vein phlebitis. Diagnostic procedures for SLE should also be introduced in patients diagnosed with anetoderma and atrophie blanche.

\section{DRUG-INDUCED LUPUS ERYTHEMATOSUS}

Similarly to SLE, drug-induced lupus erythematosus (DILE) is classified as a disease of autoimmune origin. Common shared manifestations include muscle and joint pain, serositis and general weakness. The clinical presentation of DILE differs from the idiopathic form of lupus in terms of a milder course. Patients typically have no central nervous system or kidney involvement. Also, a lower degree of photosensitivity and absence of Raynaud's phenomenon are noted. Skin abnormalities display slightly different features, with a tendency to form petechal lesions. In addition, erythema nodosum-type lesions are more frequently observed. As opposed to the idiopathic form, the onset of the disease is less rapid. Epidemiological data show that DILE occurs more frequently in the elderly population of Caucasian origin, in both sexes equally - without a predilection for women which is typical in SLE. Laboratory tests significantly less often demonstrate leukopaenia, anaemia, thrombocytopaenia, reduced concentration of $\mathrm{C} 3$ and $\mathrm{C} 4$ complement components, and deviations in parameters assessing liver and kidney function. Even though antinuclear antibodies are present in both forms, antibodies directed against histones are found in nearly $90 \%$ of patients with DILE, whereas antibodies to the Sm antigen or dsDNA (specific to the idiopathic form of the disease) are not detected [21].

DILE develops as a result of chronic, usually persisting for months, drug exposure. The main drugs potentially inducing this clinical form are hydrala-
IgG lub IgM rozproszone w naskórku (dust like particles). Obecność złogów immunoglobulin i/lub dopełniacza w skórze niezmienionej chorobowo jest bardziej charakterystyczna dla SLE.

\section{NIESPECYFICZNE DLA TOCZNIA ZMIANY SKÓRNE TOWARZYSZĄCE TOCZNIOWI RUMIENIOWATEMU UKŁADOWEMU}

Zmiany te występują często, wiążą się z zajęciem naczyń różnego kalibru i objawiają się jako waskulopatie niedokrwienne (objaw Raynauda), zapalenie naczyń (pokrzywka naczyniowa, plamica hiperergiczna, przewlekłe i nawracające owrzodzenia, zmiany martwicze na opuszkach palców), waskulopatie zakrzepowe (livedo racemosa, obwodowa zgorzel, wybroczyny podpaznokciowe, owrzodzenia), teleangiektazje w obrębie wałów paznokciowych, guzki podskórne, nawracające zapalenie żył powierzchownych i głębokich. Diagnostykę w kierunku SLE powinno się przeprowadzić także w przypadku stwierdzenia anetodermii i atrophie blanche.

\section{TOCZEŃ POLEKOWY}

Toczeń polekowy (drug-induced lupus erythematosus - DILE), podobnie jak SLE, zaliczany jest do chorób o podłożu autoimmunologicznym. Do często występujących wspólnych objawów należą: bóle stawów i mięśni, zapalenie błon surowiczych oraz ogólne osłabienie. Obraz kliniczny DILE różni się od idiopatycznej postaci tocznia łagodniejszym przebiegiem. U pacjentów zwykle nie stwierdza się zajęcia ośrodkowego układu nerwowego i nerek. Chorzy cechują się mniejszą fotowrażliwością i brakiem objawu Raynauda. Zmiany skórne mają nieco inny charakter, występuje tendencja do tworzenia się wykwitów wybroczynowych, częściej też obserwuje się zmiany o typie rumienia guzowatego. Początek choroby w porównaniu z postacią idiopatyczną jest mniej dynamiczny. Analiza danych epidemiologicznych wskazuje na częstsze występowanie DILE u osób starszych, rasy kaukaskiej, obojga płci, bez typowej dla SLE predylekcji do płci żeńskiej. W badaniach laboratoryjnych istotnie rzadziej stwierdza się leukopenię, anemię, trombocytopenię, zmniejszone stężenie dopełniacza C3 i C4 i odchylenia w parametrach oceniających wydolność wątroby oraz nerek. Chociaż w obu postaciach obecne są przeciwciała przeciwjądrowe, to jednak przeciwciała skierowane przeciwko histonom stwierdza się u prawie $90 \%$ chorych na DILE, natomiast nie stwierdza się specyficznych dla postaci idiopatycznej przeciwciał skierowanych przeciwko antygenowi Sm lub dsDNA [21].

DILE rozwija się w wyniku przewlekłej, zwykle wielomiesięcznej ekspozycji na lek. Do podstawo- 
zine, procainamide and isoniazid. Prolonged use of hydralazine and procainamide triggers DILE in $20 \%$ of patients. It must be stressed, however, that nowadays the drugs tend to be used only sporadically, so other medicinal products are more important in clinical practice.

Even though over 90 medicinal products have been reported as potential causative factors of DILE, they are usually classified into 5 groups:

- drugs targeting TNF- $\alpha$;

- drugs directed against pathogenic microorganisms: terbinafine, minocycline, isoniazid, pyrazinamide and rifabutin;

- anticonvulsant drugs: phenytoin, sodium valproate, carbamazepine;

- antiarrhythmic drugs: procainamide, quinidine, propafenone;

- antihypertensive drugs: hydralazine, minoxidil, timolol.

Some medicinal products may cause SCLE-type cutaneous lesions (drug-induced SCLE - DISCLE) which are the dominant symptom of the disease. There are reports indicating that SCLE-type skin eruptions are induced by drugs in even up to $30 \%$ of patients. As opposed to idiopathic SCLE, skin lesions in patients with DISCLE are more severe and disseminated, and more frequently affect the face and lower extremities. In addition, the inflammatory process involves blood vessels, and bullous or erythema multiforme-like lesions may appear on the skin. Although skin eruptions may clinically present as annular lesions, more common manifestations are papular scaly skin lesions resembling psoriasis. Similarly to SCLE, vital organs such as the kidneys or the central nervous system are not involved in DISCLE. Histopathological and immunopathological examinations, and antibody profile analysis, are not useful for differentiating between the idiopathic form of the disease and DISCLE. However, antibodies to the Ro antigen, the titre of which does not decrease after drug discontinuation, serve as an immunological marker of both SCLE and DISCLE. The drugs most frequently triggering DISCLE are hydrochlorothiazide, terbinafine, calcium channel blockers, anticonvulsant drugs, TNF- $\alpha$ antagonists and proton pump inhibitors [22].

Drug-induced lesions of the DLE type are reported extremely rarely. Medicinal products which have the ability to induce both DISCLE and DLE include terbinafine, TNF- $\alpha$ antagonists and anticonvulsant medications.

Unfortunately, the pathogenetic mechanism underlying the development of clinical lesions has not been fully elucidated. The effect of genetic predisposition, particularly N-acetyltransferase deficiency, is considered. DILE develops more frequently in wych leków, które są przyczyną tej postaci klinicznej, należą: hydralazyna, prokainamid i izoniazyd. W przypadku przewlekłego stosowania hydralazyny i prokainamidu DILE występuje u 20\% leczonych. Należy podkreślić, że leki te są obecnie stosowane sporadycznie, dlatego w praktyce klinicznej większe znaczenie mają inne preparaty.

Chociaż opisano ponad 90 różnych preparatów, które mogą wywołać DILE, to najczęściej zaliczane są one do 5 grup:

- leki działające na TNF- $\alpha$;

- leki skierowane przeciwko patogennym drobnoustrojom: terbinafina, minocyklina, izoniazyd, pyrazynamid, ryfabutyna;

- leki przeciwdrgawkowe: fenytoina, walproinian sodu, karbamazepina;

- leki antyarytmiczne: prokainamid, chinidyna, propafenon;

- leki obniżające ciśnienie: hydralazyna, minoksydyl, tymolol.

Niektóre preparaty mogą indukować zmiany skórne o typie SCLE (drug induced SCLE - DISCLE), które stanowią dominujący objaw choroby. Istnieją prace wskazujące, że nawet u 30\% chorych wykwity o typie SCLE mają charakter polekowy. W przeciwieństwie do idiopatycznej postaci SCLE u osób z DISCLE zmiany skórne są bardziej nasilone i rozsiane, częściej występują na twarzy i kończynach dolnych, proces zapalny obejmuje naczynia, mogą pojawiać się zmiany pęcherzowe lub przypominające rumień wielopostaciowy. Klinicznie wykwity mogą mieć charakter obrączkowaty, jednak częściej obserwuje się zmiany grudkowo-złuszczające przypominające łuszczycę. Podobnie jak w przebiegu SCLE również w DISCLE ważne dla życia narządy, takie jak nerki czy ośrodkowy układ nerwowy, nie są zajęte. Badania histopatologiczne i immunopatologiczne, jak również analiza profilu przeciwciał nie są pomocne w różnicowaniu postaci idiopatycznej i DISCLE. Markerem immunologicznym postaci SCLE oraz DISCLE są przeciwciała skierowane przeciwko antygenowi Ro, których miano nie zmniejsza się po odstawieniu leku. Klasycznymi lekami, które przyczyniają się do rozwoju DISCLE, są: hydrochlorotiazyd, terbinafina, inhibitory kanału wapniowego, leki przeciwdrgawkowe, antagoniści TNF- $\alpha$ i inhibitory pompy protonowej [22].

Niezwykle rzadko opisywane są przypadki zmian polekowych o typie DLE. Do preparatów, które mogą wywołać zarówno DISCLE, jak i DLE, należą: terbinafina, antagoniści TNF- $\alpha$ oraz leki przeciwdrgawkowe.

Niestety do dziś patogenetyczny mechanizm rozwoju zmian klinicznych nie jest w pełni poznany. Rozważa się wpływ predyspozycji genetycznych, zwłaszcza deficyt $N$-acetylotransferazy. U osób, u których procesy acetylacji są spowolnione, częściej 
patients with slower acetylation processes. Reactive drug metabolites may stimulate the process of antibody formation.

\section{RISK FACTORS FOR THE DEVELOPMENT OF CUTANEOUS FORMS OF LUPUS ERYTHEMATOSUS AND PROPHYLACTIC MANAGEMENT}

An increased risk of developing cutaneous forms of lupus erythematosus is attributable to genetic factors, immune disorders, environmental factors, and their interplay. The most important environmental factor inducing the pathological process is UV radiation, both in the UVB and UVA ranges. Active and passive smoking represents another factor associated with an increased risk of higher severity of skin lesions, and a cause of the inefficacy of antimalarial drugs. There are known cases in which cutaneous lesions were triggered by compression, scratching, burn and other factors being an expression of the isomorphic response.

Consequently, prophylactic management should involve determining drugs used by the patient and, if needed, their discontinuation or switching to another class of medications. In addition, patients should be educated about the dangers of solar radiation and advised to use appropriate photoprotection and avoid tobacco smoke. Another prophylactic measure is vitamin D supplementation in all patients with lupus erythematosus [23]. Pregnancy may be a cause of disease exacerbation, so it should be planned during remission. The recommendation applies in particular to patients with SLE and women with severe and diffuse CLE-type lesions. It needs to be stressed, though, that lupus is not an indication for pregnancy termination. Yet another problem to consider is related to vaccinations which can contribute to an exacerbation of the patient's clinical condition. The issue is not easy to resolve, and the ratio of potential risks to benefits should be considered in each individual case. The currently prevailing view is that vaccines containing inactivated pathogens or their fragments do not produce any negative effect on the course of lupus. Consequently, patients should be vaccinated according to the recommended schedule, similarly to the general population. Pneumococcal vaccines are recommended in lupus patients, and influenza vaccines are indicated in patients receiving immunosuppressive treatment. Live vaccines containing attenuated microbes should not be used in patients during immunosuppressive therapy [24]. występuje DILE. Reaktywne metabolity leków mogą stymulować proces tworzenia się przeciwciał.

\section{CZYNNIKI RYZYKA ROZWOJU SKÓRNYCH POSTACI TOCZNIA RUMIENIOWATEGO I POSTĘPOWANIE PROFILAKTYCZNE}

Na zwiększone ryzyko rozwoju skórnych postaci tocznia rumieniowatego wpływają czynniki genetyczne, zaburzenia immunologiczne, czynniki środowiskowe i wzajemne ich oddziaływanie. Najistotniejszym czynnikiem środowiskowym indukującym proces chorobowy jest promieniowanie UV i to zarówno w zakresie UVB, jak i UVA. Czynne $\mathrm{i}$ bierne palenie tytoniu jest kolejnym czynnikiem ryzyka nasilenia zmian skórnych oraz przyczyną braku skuteczności preparatów przeciwmalarycznych. Znane są przypadki rozwoju zmian skórnych prowokowanych uciskiem, drapaniem, oparzeniem i innymi czynnikami będące odzwierciedleniem objawu izomorficznego.

Dlatego w postępowaniu profilaktycznym należy uwzględnić wywiad dotyczący stosowanych przez pacjenta leków i ewentualne ich odstawienie lub zamianę na inną grupę. Wskazana jest także edukacja pacjentów obejmująca informację o szkodliwości działania promieniowania słonecznego, konieczności stosowania właściwej fotoprotekcji oraz unikania dymu tytoniowego. Kolejnym elementem postępowania profilaktycznego jest suplementacja witaminą D u wszystkich chorych na toczeń rumieniowaty [23]. U chorych na toczeń ciąża może być przyczyną zaostrzeń choroby i dlatego powinna być planowana w okresie remisji, zwłaszcza u pacjentek z SLE oraz $\mathrm{u}$ chorych z nasilonymi i rozsianymi zmianami typu CLE. Należy pamiętać, że toczeń nie jest wskazaniem do przerwania ciąży. Problem stanowią również szczepienia, które mogą się przyczynić do pogorszenia stanu klinicznego. Odpowiedź na to pytanie nie jest prosta. W każdej sytuacji należy rozważyć potencjalne ryzyko oraz korzyści. Obecnie przeważa pogląd wskazujący na brak negatywnego wpływu na przebieg tocznia szczepionek zawierających inaktywowane drobnoustroje lub ich fragmenty. Chorzy powinni otrzymywać szczepienia zgodne z kalendarzem, podobnie jak w populacji ogólnej. Szczepionki przeciwko pneumokokom są rekomendowane dla chorych na toczen, natomiast szczepienia przeciwko grypie dla chorych otrzymujących leczenie immunosupresyjne. Szczepionki żywe, zawierające pozbawione zjadliwości drobnoustroje nie powinny być stosowane $\mathrm{w}$ trakcie terapii immunosupresyjnej [24]. 


\section{HORMONE THERAPY AND PREGNANCY}

Contraceptives and hormone replacement therapy based on oestrogen-containing drugs are not recommended in patients with CLE and coexisting antiphospholipid syndrome. In cases of disease exacerbation in pregnant or breast-feeding women the drug of choice is hydroxychloroquine (HCQ) at a standard dose. If treatment needs to be continued on a long-term basis, antimalarial drugs can be used during pregnancy. However, it is necessary to replace chloroquine (CQ) with hydroxychloroquine $[25,26]$.

If HCQ proves to be ineffective in pregnant or breast-feeding women, and the disease exacerbates despite treatment, Disulone (group C) can be introduced. Systemic glucocorticosteroid (GCS) therapy at a dose not exceeding 10-15 mg/day (prednisolone) is used in justified cases. Prednisolone is the preferred medication, as it is largely metabolized in the placenta, which minimizes foetal exposure to GC. Methotrexate (MTX), mycophenolate mofetil (MMF) and retinoids must not be used throughout this period [5].

Women of reproductive age should use effective contraception during immunosuppressive treatment. Anti-Ro antibodies in maternal serum should be monitored in pregnancy on account of the risk of their passive transfer and the development of neonatal lupus erythematosus (NLE) in the child. Integrated management involving a gynaecologist, cardiologist, dermatologist and rheumatologist is advisable.

\section{TREATMENT}

In view of a broad diversity of clinical symptoms and varying severity of the disease process, there is no unified therapeutic procedure. In recent years, there has been a tendency to apply personalized treatment aimed at achieving total or partial remission of symptoms and organ manifestations (treat-to-target strategy) [5]. An improvement in the treatment of cutaneous forms of lupus erythematosus is most commonly attained with topical therapy combined with photoprotection. If no improvement is noted, systemic therapy should be added to the initial regimen, with antimalarial agents as the drugs of first choice.

\section{Topical treatment}

Since topical application of GCS medications is effective in all cutaneous forms of LE, it is indicated for first-line treatment. Higher-potency GCS are more effective than GCS producing a less potent effect. However, drugs from this class should be used periodically, for not longer than a few weeks, on account of the risk of adverse reactions. This therapeutic regimen can be applied repeatedly. In cases

\section{TERAPIA HORMONALNA I CIAZZA}

Kobietom z CLE i współistniejącym zespołem antyfosfolipidowym nie zaleca się stosowania środków antykoncepcyjnych i hormonalnej terapii zastępczej opartych na lekach zawierających estrogeny. W przypadku zaostrzenia procesu chorobowego u kobiet w ciąży lub karmiących piersią lekiem $\mathrm{z}$ wyboru jest hydroksychlorochina (HCQ) w standardowej dawce. Gdy konieczne jest przewlekłe leczenie, leki przeciwmalaryczne można stosować w czasie ciąży. Istnieje jednak potrzeba zastąpienia chlorochiny (CQ) hydroksychlorochiną $[25,26]$.

U kobiet w ciąży lub karmiących, u których HCQ nie jest skuteczna i pomimo leczenia nastąpiło zaostrzenie procesu chorobowego, można zastosować Disulone (grupa C). Ogólne leczenie glikokortykosteroidami (GKS) w dawce nie większej niż 10-15 mg/dobę (prednizolon) stosuje się w uzasadnionych przypadkach. Preferowanym preparatem jest prednizolon, który głównie metabolizowany jest w łożysku, stąd też narażenie płodu na działanie GKS jest najmniejsze. W tym czasie nie można stosować metotreksatu (MTX), mykofenolanu mofetylu (MMF) i retinoidów [5].

$\mathrm{U}$ kobiet w okresie rozrodczym podczas leczenia immunosupresyjnego należy koniecznie stosować skuteczne metody antykoncepcyjne. $\mathrm{W}$ okresie ciąży powinno się monitorować obecność przeciwciał anty-Ro w surowicy matki ze względu na możliwość ich biernego przeniesienia i rozwoju NLE (neonatal lupus erythematosus) u dziecka. Wskazane jest współdziałanie specjalistów w dziedzinie ginekologii, kardiologii, dermatologii, reumatologii.

\section{LECZENIE}

Z uwagi na różnorodność objawów klinicznych i odmienne nasilenie procesu chorobowego nie ma jednolitego postępowania terapeutycznego, a w ostatnich latach dominuje tendencja do leczenia spersonalizowanego, ukierunkowanego na osiągnięcie całkowitej lub częściowej remisji objawów i zmian narządowych (treat to target) [5]. W leczeniu skórnych postaci tocznia rumieniowatego najczęściej uzyskuje się poprawę, stosując terapię miejscową i fotoprotekcję. W przypadku braku poprawy należy dołączyć leczenie ogólne, w pierwszej kolejności preparaty przeciwmalaryczne.

\section{Leczenie miejscowe}

Miejscowa aplikacja GKS jest skuteczna we wszystkich skórnych postaciach LE, dlatego jest zalecana jako leczenie pierwszego wyboru. Glikokortykosteroidy o wyższej sile działania są bardziej skuteczne niż GKS o słabszym działaniu. Ze względu jednak na działania niepożądane leki z tej grupy należy stosować okresowo, nie dłużej niż kilka tygodni. Ten sposób terapii można powtarzać wielokrotnie. W przypadku zmian 
of diffuse lesions, or a tendency to scarring, antimalarial medications should be added to the topical therapy.

An equally effective option in the topical treatment of CLE is to introduce calcineurin inhibitors, particularly in the therapy of facial lesions with pronounced erythema and oedema. They are indicated as firstline drugs or for continued treatment after the withdrawal of topical GCS. Patients with diffuse lesions or a tendency to scarring can also be treated with combined therapy with antimalarial medications [5].

Topical retinoids should be considered in patients affected by skin lesions with hypertrophy or refractory to currently used treatment. Topical phototherapy, laser therapy and cryotherapy are not recommended [5].

\section{Systemic treatment (table 2)}

\section{Antimalarial medications}

Systemic treatment with antimalarial drugs is not only effective in all cutaneous forms of lupus erythematosus, but it can also prevent organ involvement [27]. The above applies in particular to HCQ. The drug prolongs periods of remission, decreases the number of relapses and reduces damage to internal organs even in the course of lupus nephritis. Before starting therapy with antimalarial medications patients should preferably be given an ophthalmological examination. Annual ophthalmological assessments are required only in high-risk patients and all individuals taking the drug for more than 5 years. A first-line drug recommended in all clinical subtypes of CLE, particularly in severe and disseminated cases, is HCQ because of its superior safety profile to CQ [28]. Antimalarials are especially useful in the treatment of patients at a risk of organ involvement. The maximum daily doses of HCQ and CQ are $5-6.5 \mathrm{mg} / \mathrm{kg}$ of normal body weight, and 2.3-3 mg/ kg of normal body weight, respectively. The drugs should not be combined because of their potentially toxic effect on the eyes. If treatment with

Table 2. Systemic treatment of cutaneous lupus erythematosus

\begin{tabular}{l} 
First-line drugs \\
Hydroxychloroquine, chloroquine \\
\hline Glucocorticosteroids \\
Second-line drugs \\
Methotrexate \\
\hline Acitretin \\
\hline Isotretinoin \\
\hline Sulphones (first-line drugs in the bullous form) \\
Third-line drugs \\
Mycophenolate mofetil
\end{tabular}

o charakterze rozsianym lub z tendencją do bliznowacenia wskazane jest dołączenie do leczenia miejscowego środków przeciwmalarycznych.

W terapii miejscowej CLE równie skuteczne są inhibitory kalcyneuryny, zwłaszcza w leczeniu zmian na twarzy, z nasilonym rumieniem i obrzękiem. Zalecane są one jako leki pierwszego wyboru lub kontynuacja terapii po odstawieniu miejscowych GKS. U chorych z rozsianymi wykwitami lub tendencją do bliznowacenia można zastosować leczenie skojarzone z lekami przeciwmalarycznymi [5].

W przypadku przerostowych zmian skórnych lub zmian opornych na dotychczasowe leczenie należy rozważyć miejscowe zastosowanie retinoidów. Nie zaleca się miejscowej foto-, lasero- i krioterapii [5].

\section{Leczenie ogólne (tab. 2)}

Preparaty przeciwmalaryczne

Terapia ogólna lekami przeciwmalarycznymi jest nie tylko skuteczna we wszystkich skórnych postaciach tocznia rumieniowatego, lecz może także zapobiegać rozwojowi zmian narządowych [27]. Dotyczy to zwłaszcza HCQ. Lek ten wydłuża okresy remisji, zmniejsza liczbę nawrotów, a także ogranicza uszkodzenie narządów wewnętrznych, nawet w przebiegu lupus nephritis. Przed włączeniem preparatów przeciwmalarycznych rekomendowane jest badanie okulistyczne. Coroczna kontrola okulistyczna wymagana jest jedynie $\mathrm{u}$ chorych z grupy wysokiego ryzyka i u wszystkich, którzy przyjmują lek ponad 5 lat. We wszystkich podtypach klinicznych CLE, zwłaszcza w przypadkach nasilonych i rozsianych, jako lek pierwszego wyboru rekomendowana jest $H C Q$, ponieważ ma lepszy profil bezpieczeństwa niż CQ [28]. Leki przeciwmalaryczne są szczególnie przydatne w leczeniu pacjentów z ryzykiem rozwoju zmian narządowych. Maksymalna dzienna dawka dla HCQ wynosi 5-6,5 mg/ kg należnej masy ciała, natomiast dla CQ - 2,3-3 mg/kg należnej masy ciała. Nie należy łączyć tych leków ze względu na potencjalnie toksyczne działanie na narząd wzroku. U chorych, u których obserwuje się brak skuteczności terapii HCQ

Tabela 2. Leczenie ogólne skórnej postaci tocznia rumieniowatego

\begin{tabular}{l} 
Leki pierwszego wyboru \\
hydroksychlorochina, chlorochina \\
\hline glikokortykosteroidy \\
Leki drugiego wyboru \\
metotreksat \\
\hline acytretyna \\
\hline izotretynoina \\
\hline sulfony (lek pierwszego wyboru w postaci pęcherzowej) \\
Leki trzeciego wyboru \\
mykofenolan mofetylu
\end{tabular}


HCQ and CQ proves ineffective or there are contraindications to using drugs from this class, quinacrine at a dose of $100 \mathrm{mg} /$ day is recommended. It must be stressed, though, that the drug is not available in Poland (based on 2017 data). As a result, the physician must file a "request for importation of a medicinal product necessary to save a patient's life or health approved for marketing without the need to acquire a marketing authorization" (Appendix to the Regulation of the Minister of Health of 21 March 2012). The most common side effect of using the drug is the yellowing of the skin and mucous membranes. Severe but extremely rare complications include the development of dysplastic anaemia Complications depend on the dose and duration of therapy. Haemolysis as a complication of treatment with antimalarial drugs occurs in patients with glucose-6-phosphate dehydrogenase deficiency. Therefore, determining the concentration of the enzyme before the initiation of therapy is recommended $[5,29,30]$.

\section{Systemic use of glucocorticosteroids}

Systemic glucocorticosteroid therapy shows the highest efficacy in the treatment of CLE, however in view of potential adverse effects systemic glucocorticosteroids are indicated in cases of CLE with a severe course and disseminated character. The recommended dose is $0.5-1 \mathrm{mg} / \mathrm{kg} /$ day of prednisone/methylprednisone or equivalent doses of other GCS [15, 20]. In some patients it is possible to achieve a good therapeutic effect after using a lower dose of GCS. In justified cases, pulses of methylprednisolone at a dose of $1 \mathrm{~g}$ are administered [5]. The duration of therapy should be reduced as far as possible in response to clinical improvements seen in patients, until its complete discontinuation $[29,30]$.

\section{Methotrexate}

Methotrexate is another drug used in cases which are refractory to previous therapeutic modalities. The standard dose of the medication is $15-25 \mathrm{mg} /$ week. Methotrexate is recommended for second-line therapy, especially in cases of SCLE and in combination with antimalarial drugs [5].

\section{Retinoids}

Retinoids are generally recognized as second-line drugs, particularly in patients with DLE and SCLE not responding to prior therapy. Retinoids are indicated specifically in CLE cases with a tendency for hypertrophy and hyperkeratosis. The recommended dose of acitretin and isotretinoin is $0.2-1 \mathrm{mg} / \mathrm{kg} /$ day. The drugs produce teratogenic effects, so contraception must be used both during and after the end of treatment (isotretinoin: 1 month, acitretin: 3 years). i CQ lub istnieją przeciwwskazania do stosowania leków z tej grupy, zalecana jest chinakryna w dawce $100 \mathrm{mg} /$ dobę. Należy jednak pamiętać, że lek ten nie jest dostępny w Polsce (wg danych z 2017 r.). W tych przypadkach należy wypełnić wniosek „zapotrzebowanie na sprowadzenie $\mathrm{z}$ zagranicy produktu leczniczego, niezbędnego dla ratowania życia lub zdrowia pacjenta, dopuszczonego do obrotu bez konieczności uzyskania pozwolenia" (załącznik do Rozporządzenia Ministra Zdrowia z dnia 21 marca 2012 r.). Do najczęstszych objawów ubocznych powstałych w wyniku stosowania tego leku należą żółtawe zabarwienie skóry i błony śluzowej. Do ciężkich, ale wyjątkowych powikłań, zalicza się niedokrwistość dysplastyczną. Zależne są one od dawki i czasu stosowania terapii. Hemoliza jako powikłanie leczenia preparatami antymalarycznymi występuje u pacjentów $\mathrm{z}$ defektem dehydrogenazy glukozo-6-fosforanowej. Dlatego przed rozpoczęciem terapii wskazane jest oznaczenie stężenia tego enzymu $[5,29,30]$.

\section{Ogólne stosowanie glikokortykosteroidów}

Ogólna glikokortykosteroidoterapia jest najbardziej skuteczna w leczeniu CLE, jednak ze względu na możliwe działania niepożądane wskazaniem do stosowania tych leków są przypadki CLE o ciężkim przebiegu i rozsianym charakterze. Zalecana dawka to 0,5-1 mg/ $\mathrm{kg}$ m.c./dobę prednizonu lub metyloprednizonu, lub równoważne dawki innych GKS [15, 20]. U części pacjentów możliwe jest uzyskanie dobrego efektu terapeutycznego po zastosowaniu mniejszej dawki GKS. W uzasadnionych przypadkach stosowane są pulsy z 1 g metyloprednizolonu [5]. Czas leczenia GKS należy maksymalnie skracać wraz z poprawą kliniczną, aż do całkowitego odstawienia GKS [29, 30].

\section{Metotreksat}

Kolejnym lekiem stosowanym w postaciach opornych na wcześniejsze metody terapeutyczne jest metotreksat, podawany zwykle w dawce 15-25 mg tygodniowo. Zalecany jest jako lek drugiego wyboru, zwłaszcza w przypadkach SCLE i w skojarzeniu z lekami przeciwmalarycznymi [5].

\section{Retinoidy}

Retinoidy stosowane ogólnie uznawane są za lek drugiego wyboru, zwłaszcza w niepowodzeniu leczniczym u pacjentów z DLE i SCLE. Retinoidy są szczególnie wskazane w przypadkach CLE $\mathrm{z}$ tendencją do przerostu i hiperkeratozy. Zalecaną dawką dla acytretyny i izotretynoiny jest $0,2-1 \mathrm{mg} / \mathrm{kg}$ m.c./ dobę. Ze względu na ich teratogenne działanie konieczne jest stosowanie antykoncepcji w czasie leczenia i po jego zakończeniu (izotretynoina 1 miesiąc, acytretyna 3 lata). Skojarzona terapia retinoidami i lekami przeciw- 
Combined treatment with retinoids and antimalarial drugs is more effective than the medications used in monotherapy $[5,29,30]$.

\section{Sulphones}

Sulphones (disulone) are effective in the treatment of SCLE, LEP, urticarial vasculitis and oral mucosal ulcers. Sulphones have a special indication for the therapy of the bullous form of the disease, producing a remission in cases not responding to antimalarial drugs and GCS [10]. In other forms of CLE sulphones are recommended as second-line drugs in combination with antimalarials. Disulone treatment in Poland requires importation of the drug from abroad according to the procedure described above which is laid down in the applicable Regulation of the Minister of Health. The recommended initial dose ( $50 \mathrm{mg} /$ day) can be gradually increased to the maximum dose of $1.5 \mathrm{mg} / \mathrm{kg}$ depending on the level of clinical improvement observed in the patient and the development of adverse effects which usually comprise haematological and neurological disorders. Other potential adverse effects include vomiting, headache and dizziness, and general weakness. An increase in the concentration of methaemoglobin results from the oxidation of haemoglobin and manifests clinically as dyspnoea, headaches and peripheral cyanosis. To lower the risk of adverse effects, the activity of glucose6-phosphate dehydrogenase should be assessed in patients prior to starting treatment $[29,30]$.

\section{Other drugs}

Mycophenolate mofetil belongs to the group of third-line drugs indicated for the treatment of CLE cases refractory to previous therapeutic modalities. Mycophenolate mofetil is recommended to be used in combination with antimalarial drugs. The initial dose of $2 \times 500 \mathrm{mg}$ can be increased to $3 \mathrm{~g} /$ day depending on the clinical effect. It is advisable to monitor blood cell counts and liver and kidney function on a monthly basis during the treatment.

Other immunosuppressive drugs such as azathioprine, cyclophosphamide, cyclosporin or the biologic drug belimumab are not indicated in patients without organ/systemic involvement. Therapeutic modalities which are not recommended for the therapy of CLE include intravenous immunoglobulin infusions, anti-CD4 antibodies, anti-TNF- $\alpha$ antibodies, rituximab, INF- $\alpha$, leflunomide, danazol and extracorporeal photopheresis [5].

The therapeutic solutions presented above are not intended to be an endorsement of any particular product or manufacturer. Therapeutic decisions should be made individually for each patient after consideration of such aspects as potential efficacy, contraindications and safety profile. malarycznymi jest bardziej skuteczna niż te preparaty zastosowane w monoterapii [5, 29, 30].

\section{Sulfony}

Sulfony (disulone) są skuteczne w leczeniu SCLE, LEP, urticarial vasculitis i zmian wrzodziejących błony śluzowej jamy ustnej. Szczególnym wskazaniem do ich stosowania jest postać pęcherzowa, w której uzyskuje się remisję pomimo braku skuteczności leków przeciwmalarycznych i GKS [10]. W pozostałych postaciach CLE sulfony zaleca się jako leki drugiego wyboru w skojarzeniu ze środkami przeciwmalarycznymi. Disulone należy również sprowadzić z zagranicy zgodnie z opisaną powyżej procedurą zawartą w Rozporządzeniu Ministra Zdrowia. Rekomendowaną dawkę początkową $50 \mathrm{mg} /$ dobę można stopniowo zwiększać, maksymalnie do $1,5 \mathrm{mg} / \mathrm{kg}$ m.c., w zależności od uzyskiwanej poprawy klinicznej i rozwoju objawów ubocznych, do których najczęściej należą zaburzenia hematologiczne i neurologiczne. Do innych potencjalnych objawów niepożądanych zalicza się: wymioty, bóle i zawroty głowy oraz ogólne osłabienie. Wzrost stężenia methemoglobiny wywołany jest utlenieniem hemoglobiny, czego odzwierciedleniem są: duszność, bóle głowy i sinica obwodowa. W celu zmniejszenia ryzyka rozwoju objawów niepożądanych wskazane jest oznaczenie aktywności dehydrogenazy glukozo-6-fosforanowej przed podjęciem leczenia $[29,30]$.

Inne leki

Mykofenolan mofetylu zaliczany jest do leków trzeciego wyboru w przypadkach CLE opornych na dotychczasowe metody leczenia. Wskazane jest kojarzenie go z lekami przeciwmalarycznymi. Początkową dawkę 2 × 500 mg można zwiększać do $3 \mathrm{~g} /$ dobę w zależności od efektu klinicznego. W czasie leczenia wskazana jest comiesięczna kontrola parametrów krwi, funkcji wątroby i nerek.

Inne leki immunosupresyjne, takie jak azatiopryna, cyklofosfamid, cyklosporyna lub lek biologiczny belimumab, nie są wskazane $u$ pacjentów bez zmian narządowych lub ogólnoustrojowych. Do leczenia CLE nie są rekomendowane: dożylne wlewy immunoglobulin, przeciwciała anty-CD4, anty-TNF- $\alpha$, rytuksymab, INF- $\alpha$, leflunomid, danazol i zewnątrzustrojowa fotofereza [5].

Prezentowane $\mathrm{w}$ tym opracowaniu rozwiązania terapeutyczne nie stanowią rekomendacji żadnego konkretnego produktu lub producenta. Należy pamiętać, że decyzje terapeutyczne podejmuje się w zależności od potencjalnej skuteczności, przeciwwskazań i profilu bezpieczeństwa, dostosowując leczenie dla każdego pacjenta indywidualnie. 
Skin lesions not only play a significant role in the diagnostic process, but also indicate the efficacy of treatment received by patients. Verification of diagnosis in patients with CLE is recommended during each follow-up appointment on the basis of clinical examination and evaluation of new skin lesions (both typical and atypical for lupus). Histopathological analysis should be considered in uncertain cases, particularly in the hypertrophic form of the disease, because of the possibility of neoplastic transformation.

During the active period of the disease, patients should be examined each time to evaluate their fulfilment of the diagnostic criteria of SLE. Other tests that should be performed in this group of patients include follow-up urinalysis (with 24-hour urine protein test), CBC, ESR, proteinogram, concentration of serum creatinine or GFR and complement components (C3 and C4). In patients with previously detected antinuclear antibodies their monitoring is not necessary, as the antibody titre is not correlated with the activity of the disease process. The only exception is suspected drug-induced lupus (antibodies against histones) and lupus nephritis (dsDNA), as well as NLE during pregnancy (anti-Ro antibodies). Patients with clinical manifestations and laboratory test abnormalities indicative of organ involvement should be considered for more in-depth diagnostics examining these organs. Alternatively, such patients may be referred for further diagnostic and therapeutic management to a specialist medical centre with expertise in the treatment of lupus. Additionally, laboratory tests should be performed to monitor adverse effects related to drug toxicity. Furthermore, in cases which become exacerbated or refractory to previously introduced treatment, the possibility of lesions corresponding to the drug-induced lupus type should be considered (mainly in SCLE).

Patients treated only with topical therapy may report for follow-up appointments on a 3-monthly basis. However, patients who require the initiation of systemic treatment or who continue such therapy should report for follow-up appointments every one to three months depending on clinical symptoms, laboratory test results and toxicity of drugs used.

Patients with CLE should have ophthalmological consultation prior to the start of treatment with antimalarial drugs (HCQ, CQ). Also, ophthalmological examinations should be repeated in the course of prolonged therapy with these drugs. Earlier ophthalmological consultations are indicated in patients who develop adverse drug reactions or have other risk factors.

During periods of disease inactivity or low activity, when no systemic symptoms are present, labora-
Zmiany skórne odgrywają nie tylko istotną rolę w procesie diagnostycznym i prognostycznym, lecz także świadczą o skuteczności stosowanego leczenia. Podczas każdej wizyty u chorych na CLE zalecana jest weryfikacja diagnozy na podstawie badania klinicznego oraz oceny nowych, typowych i nietypowych dla tocznia zmian skórnych. W przypadkach wątpliwych należy rozważyć wykonanie badania histopatologicznego. Dotyczy to zwłaszcza postaci przerosłej ze względu na możliwość transformacji nowotworowej.

U pacjentów w aktywnym okresie choroby należy każdorazowo przeprowadzić badanie pod kątem spełnienia kryteriów diagnostycznych dla SLE. Ponadto należy wykonać kontrolne badanie moczu (z uwzględnieniem obecności białka w dobowej zbiórce moczu), morfologię krwi, OB, proteinogram, oznaczyć stężenie kreatyniny w surowicy lub GFR, poziom składowych komplementu (C3, C4). W przypadku wcześniej stwierdzonych przeciwciał przeciwjądrowych ich monitowanie nie jest konieczne, ponieważ miano nie koreluje $\mathrm{z}$ aktywnością procesu chorobowego. Wyjątkiem jest jednak podejrzenie tocznia polekowego (przeciwciała skierowane przeciwko histonom) i nerkowego (dsDNA), a także NLE w przebiegu ciąży (przeciwciała anty-Ro). U osób z objawami klinicznymi i odchyleniami w badaniach laboratoryjnych wskazującymi na rozwój zmian narządowych należy rozważyć pogłębienie diagnostyki w zakresie tych organów lub skierowanie do ośrodka specjalistycznego mającego doświadczenie w terapii tocznia do dalszej diagnostyki i leczenia. Dodatkowo powinno się wykonywać badania laboratoryjne w celu monitorowania objawów niepożądanych związanych z toksycznością leków. Ponadto w przypadkach zaostrzenia lub oporności na dotychczasowe leczenie należy rozpatrzyć możliwość obecności zmian o typie tocznia polekowego (zwłaszcza w przypadku postaci SCLE).

U pacjentów stosujących wyłącznie leczenie miejscowe wizyty kontrolne mogą odbywać się co 3 miesiące. Chorym, u których wymagane jest zastosowanie leczenia ogólnego lub jego kontynuacja, zaleca się wizyty kontrolne co 1-3 miesięcy w zależności od objawów klinicznych, wyników badań laboratoryjnych i toksyczności stosowanych leków.

U chorych na CLE przed podjęciem leczenia preparatami przeciwmalarycznymi (HCQ, CQ) wymagana jest konsultacja okulistyczna, którą należy powtarzać w trakcie przewlekłego stosowania tych leków. Wcześniejsze wizyty u okulisty wskazane są w przypadku wystąpienia jakichkolwiek objawów niepożądanych stosowania tych leków lub istnienia innych czynników ryzyka. 
tory monitoring is not required, with the exception of follow-up focusing on the toxicity of drugs taken by the patient. Immunosuppressive treatment is associated with an elevated risk of bacterial, viral and fungal infections. Also, it may contribute to the development of cancers. Consequently, women should have annual gynaecological examinations including a cervical screening test once a year [24].

The withdrawal of treatment is recommended in patients without organ manifestations and a year after the resolution of skin lesions. Patients who no longer receive treatment may have follow-up appointments with a dermatologist or general practitioner.

\section{CONFLICT OF INTEREST}

The authors declare no conflict of interest.
Pacjenci będący w okresie nieaktywnym choroby lub słabej jej aktywności, bez objawów ogólnych nie wymagają monitorowania laboratoryjnego poza kontrolą związaną z toksycznością stosowanych leków. Leczenie immunosupresyjne obarczone jest zwiększonym ryzykiem rozwoju infekcji bakteryjnych, wirusowych i grzybiczych, a także może się przyczynić do rozwoju nowotworów. Dlatego też kobietom zalecana jest systematyczna kontrola ginekologiczna włącznie $z$ badaniem cytologicznym szyjki macicy raz w roku [24].

Zaprzestanie leczenia wskazane jest $\mathrm{u}$ chorych bez objawów narządowych i rok po ustąpieniu zmian skórnych. Pacjenci po zakończeniu leczenia powinni regularnie zgłaszać się na wizyty kontrolne do dermatologa-wenerologa lub lekarza rodzinnego.

\section{KONFLIKT INTERESÓW}

Autorzy nie zgłaszają konfliktu interesów.

\section{References}

\section{Piśmiennictwo}

1. Arbuckle M.R., McClain M.T., Rubertone M.V., Scofield R.H., Dennis G.J., James J.A., et al.: Development of autoantibodies before the clinical onset of systemic lupus erythematosus. N Engl J Med 2003, 16, 1526-1533.

2. Szczęch J., Samotij D., Werth V.P., Reich A.: Trigger factors of cutaneous lupus erythematosus: a review of current literature. Lupus 2017, 26, 791-807.

3. Stannard J.N., Kahlenberg J.M.: Cutaneous lupus erythematosus: updates on pathogenesis and associations with systemic lupus. Curr Opin Rheumatol 2016, 28, 453-459.

4. Petri M., Orbai A.M., Alarcón G.S., Gordon C., Merrill J.T., Fortin P.R., et al.: Derivation and validation of the Systemic Lupus International Collaborating Clinics classification criteria for systemic lupus erythematosus. Arthritis Rheum 2012, 64, 2677-2686.

5. Kuhn A., Aberer E., Bata-Csörgó Z., Caproni M., Dreher A., Frances C., et al.: S2k guideline for treatment of cutaneous lupus erythematosus - guided by the European Dermatology Forum (EDF) in cooperation with the European Academy of Dermatology and Venereology (EADV). J Eur Acad Dermatol Venereol 2017, 31, 389-404.

6. Hochberg M.C.: Updating the American College of Rheumatology revised criteria for the classification of systemic lupus erythematosus. Arthritis Rheum 1997, 40, 1725.

7. Pisetsky D.S.: Antinuclear antibody testing - misunderstood or misbegotten? Nat Rev Rheumatol 2017, 13, 495-502.

8. Patsinakidis N., Gambichler T., Lahner N., Moellenhoff K., Kreuter A.: Cutaneous characteristics and association with antinuclear antibodies in 402 patients with different subtypes of lupus erythematosus. J Eur Acad Dermatol Venereol 2016, 30, 2097-2104.

9. Li A.W., Weed J.G., Stamey C.R., Subtil A., Tomayko M.M., Antaya R.J.: Bullous systemic lupus erythematosus in a 6-yearold boy. Pediatr Dermatol 2017, 34, e313-e316.

10. Contestable J.J., Edhegard K.D., Meyerle J.H.: Bullous systemic lupus erythematosus: a review and update to diagnosis and treatment. Am J Clin Dermatol 2014, 15, 517-524.

11. Yildirim Cetin G., Sayar H., Ozkan F., Kurtulus S., Kesici F., Sayarlioglu M.: A case of toxic epidermal necrolysis-like skin lesions with systemic lupus erythematosus and review of the literature. Lupus 2013, 22, 839-846.

12. Monga B., Ghosh S., Jain V.: Toxic epidermal necrolysis-like rash of lupus: a dermatologist's dilemma. Indian J Dermatol $2014,59,401-402$.

13. Kuhn A., Woźniacka A., Szepietowski J.C., Gläser R., Lehmann P., Haust M., et al.: Photoprovocation in cutaneous lupus erythematosus: a multicenter study evaluating a standardized protocol. J Invest Dermatol 2011, 131, 1622-1630.

14. Alniemi D.T., Gutierrez A., Drage L.A., Wetter D.A.: Subacute cutaneous lupus erythematosus: clinical characteristics, disease associations, treatments, and outcomes in a series of 90 patients at Mayo Clinic, 1996-2011. Mayo Clin Proc 2017, 92, 406-414.

15. Elman S.A., Joyce C., Nyberg F., Furukawa F., Goodfield M., Hasegawa M.: Development of classification criteria for discoid lupus erythematosus: results of a Delphi exercise. J Am Acad Dermatol 2017, 77, 261-267.

16. Juczyńska K., Woźniacka A., Waszczykowska E., Żebrowska A.: Lupus erythematosus panniculitis resistant to standard treatment, complicated with macrophage activation syndrome. Adv Dermatol Allergol 2017, 34, 281-283.

17. Menzies S., O'Shea F., Galvin S., Wynne B.: Oral manifestations of lupus. Ir J Med Sci 2018, 187, 91-93. 
18. Schmitt V., Meuth A.M., Amler S., Kuehn E., Haust M., Messer G., et al.: Lupus erythematosus tumidus is a separate subtype of cutaneous lupus erythematosus. Br J Dermatol 2010, 162, 64-73.

19. Su W.P., Perniciaro C., Rogers R.S., White J.W.: Chilblain lupus erythematosus (lupus pernio): clinical review of the Mayo Clinic experience and proposal of diagnostic criteria. Cutis 1994, 54, 395-399.

20. Rudnicka L., Olszewska M., Rakowska A., Kowalska-Olędzka E., Słowińska M.: Trichoscopy: a new method for diagnosing hair loss. J Drugs Dermatol 2008, 7, 651-654.

21. Kulczycka L., Kierstan M.K., Sysa-Jędrzejowska A., Robak E.: Drug induced lupus erythematosus and systemic lupus erythematosus - differences and similarities. Przegl Lek 2007, 64, 509-514.

22. Lowe G.C., Henderson C.L., Grau R.H., Hansen C.B., Sontheimer R.D.: A systematic review of drug-induced subacute cutaneous lupus erythematosus. Br J Dermatol 2011, 164, 465-472.

23. Bogaczewicz J., Karczmarewicz E., Płudowski P., Ząbek J., Woźniacka A.: Requirement for vitamin D supplementation in patients using photoprotection: variations in vitamin D levels and bone formation markers. Int J Dermatol 2016, 55, 176-183.

24. Mathian A., Arnaud L., Adoue D., Agard C., Bader-Meunier B., Baudouin V., et al.: Prevention of infections in adults and adolescents with systemic lupus erythematosus: guidelines for the clinical practice based on the literature and expert opinion. Rev Med Interne 2016, 37, 307-320.

25. Schreiber K., Breen K., Cohen H., Jacobsen S., Middeldorp S., Pavord S., et al.: Hydroxychloroquine to Improve Pregnancy Outcome in Women with Antiphospholipid Antibodies (HYPATIA) Protocol: a multinational randomized controlled trial of hydroxychloroquine versus placebo in addition to standard treatment in pregnant women with antiphospholipid syndrome or antibodies. Semin Thromb Hemost 2017, 43, 562-571.

26. Andreoli L., Bertsias G.K., Agmon-Levin N., Brown S., Cervera R., Costedoat-Chalumeau N., et al.: EULAR recommendations for women's health and the management of family planning, assisted reproduction, pregnancy and menopause in patients with systemic lupus erythematosus and/or antiphospholipid syndrome. Ann Rheum Dis 2017, 76, 476-485.

27. Woźniacka A., McCauliffe D.P.: Optimal use of antimalarials in treating cutaneous lupus erythematosus. Am J Clin Dermatol 2005, 6, 1-11.

28. Bogaczewicz A., Sobow T., Bogaczewicz J., Bieńkowski P., Kowalski J., Woźniacka A.: Chloroquine-induced subacute paranoid-like disorder as a complication of dermatological treatment. Int J Dermatol 2016, 55, 1378-1380.

29. Chang J., Werth V.P.: Therapeutic options for cutaneous lupus erythematosus: recent advances and future prospects. Expert Rev Clin Immunol 2016, 12, 1109-1121.

30. Reich A., Werth V.P., Furukawa F., Kuhn A., Szczęch J., Samotij D., et al.: Treatment of cutaneous lupus erythematosus: current practice variations. Lupus 2016, 25, 964-972.

Received: 28.12 .2017

Accepted: 28.01 .2018

Otrzymano: $28.12 .2017 \mathrm{r}$.

Zaakceptowano: $28.01 .2018 \mathrm{r}$.

How to cite this article

Woźniacka A., Sysa-Jędrzejowska A., Reich A., Szepietowski J., Błaszczyk M., Lis Święty A., Wojas-Pelc A., Krasowska D., Maj J., Rudnicka L.: Cutaneous lupus erythematosus. Diagnostic and therapeutic recommendations of the Polish Dermatological Society. Dermatol Rev/Przegl Dermatol 2018, 105, 244-263. DOI: https://doi.org/10.5114/dr.2018.75581. 